\title{
Ecclesiastical Chronotaxes of the Renaissance
}

\author{
DAMIANO ACCIARINO \\ Università Ca' Foscari Venezia
}

\begin{abstract}
During the sixteenth century, confessional disputes between Catholics and Protestants became the "battlefield" for determining and shaping the reformed Christian religion. Antiquarian erudition played a key role in this process, acting in accordance with the diverse cultural systems in place, justifying doctrinaire positions, and legitimizing the existence of their institutions. Renaissance chronotaxes illustrate this point particularly well. In this article, for the first time, the ecclesiastical chronotaxes disseminated to Christian scholarly environments throughout Renaissance Europe have been collated and studied. Both the driving forces behind this cultural phenomenon and the methods applied are investigated. The key objective here is to present the first catalogue of these works and to offer valuable material that sheds further light on the cultural, historical, and religious dynamics of the time, which may serve as the basis for further academic debate.
\end{abstract}

Pendant le seizième siècle, les disputes confessionnelles entre catholiques et protestants sont devenues le champ où s'est déroulée la bataille qui donna naissance et forme à la religion chrétienne réformée. L'érudition antiquisante a joué un rôle majeur à ce stade, comme référence commune partagée par les différents systèmes culturels qui s'affrontaient, qui permettait de justifier des positions doctrinales et de légitimer l'existence des diverses institutions confessionnelles. Les chronotaxes de la Renaissance en sont un exemple idéal. Dans cet article, pour la première fois, sont colligées et étudiées les chronotaxes ecclésiastiques, qui se sont répandues dans les milieux chrétiens érudits de l'Europe de la Renaissance. On examine à la fois les sources de ce phénomène culturel, et les méthodes de leur application. L'objectif principal de cette étude est de présenter le premier catalogue de ce phénomène, ainsi que plusieurs renseignements éclairant certaines dynamiques culturelles, historiques et religieuses de l'époque. Cela pose les bases pour la poursuite de recherches sur ce sujet.

\section{Introduction}

S ince the dawn of the Protestant Reformation, rethinking the past has been one of the fundamental aspects of spiritual renovation; history has become a tool used not only to affirm the providential role of each confessional identity, but also to debate controversial doctrinal issues. ${ }^{1}$ In their transmission of church

1. Irena D. Backus, “The Fathers and the Reformation," in Wiley Blackwell Companion to Patristics, ed. Ken Parry (Oxford: Wiley \& Sons, 2015), 428-41. See also Stephan Bauer, "La transizione storiografica tra Rinascimento e Controriforma. Il caso di Onofrio Panvinio (1530-1568)," in La transizione come problema storiografico, ed. P. Pombeni and H. G. Haupt (Bologna: il Mulino, 2013), 133; Yves

Renaissance and Reformation / Renaissance et Réforme 40.2, Spring / printemps 2017 
history, Protestants and Catholics began to use sacred scriptures (or the Divina historia $)^{2}$ as the primary ground for their own legitimacy to exist and to defend the status quo: on the Catholic side, a church with a strong vertical structure headed by the Roman pope; on the Protestant side, removal of secular hierarchy and the return to an evangelical church. Here, ecclesiastical history was used not only to justify doctrinal positions and support spiritual inclinations, but also to sustain political beliefs, all for the purpose of consolidating temporal power within the folds of the pastoral mission.

In 1593, Italian scholar and Jesuit Antonio Possevino (1533-1611) defined the concept of theologia positiva in his Bibliotheca Selecta as a method by which sacred scripture may be interpreted through the use of empirical data, demonstrating how the antiquarian perspective had influenced ecclesiastical studies by the end of the sixteenth century. ${ }^{3}$ In fact, the hermeneutical process developed by humanists throughout the decades was openly accepted as being essential for dealing with theological issues: this method of research, which had previously only been used to investigate classical antiquity, was applied with ease to church history. ${ }^{4}$

During the sixteenth century, this approach spread among and came to be followed by the scholars who dealt with sacred scriptures-before developing into an instrument of debate and discussion in order to re-elaborate upon the traditional narratives for every confessional purpose, and introducing a new ecclesiastical history, based on empirical data, that would be difficult to contest. ${ }^{5}$

Krumenacker, "La généalogie imaginaire de la Réforme protestante," in Revue Historique 308.2 (2006): 263-64; Irena D. Backus, Historical Method and Confessional Identity in the Era of the Reformation, 1378-1615 (Leiden: Brill, 2003), in which it is demonstrated that the omnipresence of a historiographic layout in the theological reflections of the Renaissance allowed the affirmation of one's own confessional identity.

2. Antonio Possevino, Bibliotheca selecta qua agitur de ratione studiorum in historia, in disciplinis, in salute omnium procuranda (Rome: Typographia Vaticana, 1593), 148. Historical analysis during the Reformation concerned especially the early Christian Church. Hubert Jedin, Riforma e Controriforma (Milan: Jaca Book, 1976), $661 \mathrm{ff}$.

3. Possevino, bk 2, ch. 1, 151-52.

4. Possevino, bk 2, ch. 1, 151; Jedin, Riforma e Controriforma, 661-71.

5. On the encounter of humanism and ecclesiastical studies during the sixteenth century, see Anthony Grafton, "Church History in Early Modern Europe: Tradition and Innovation," in Sacred Uses of the Christian Past in the Renaissance World, ed. Katherine Van Liere, Simon Ditchfield, and Howard Louthan (Oxford: Oxford University Press, 2012), 3-26, in which is also stated the fundamental distinction 
The genre of "chronotaxes," in particular, represents one of the most interesting cases of the Christian past being used to construct and defend specific confessional positions. ${ }^{6}$ This practice - an arrangement in chronological order (chrono, from the Greek $\chi \rho o ́ v o \varsigma=$ time; and taxis, from the Greek tá $\sigma \sigma \varepsilon \imath v=$ to arrange)-was a technique of time computation that linked cosmological movements with the actions of human beings in history and was used to calculate universal time and establish its relationship with events. ${ }^{7}$ These works reconstructed seriations of the names of public figures and their office in yearly progression, thereby determining their overall succession.

Although unconventional lists can be found, ${ }^{8}$ chronotaxes were usually prepared for political and ecclesiastical institutions as soon as they were

between secular and religious antiquarian research: the former sought through different disciplines an unknown past, the latter instead wanted to prove preset statements (5). See also Raphaële Mouren, La lecture assidue des classiques: Marcello Cervini et Piero Vettori, in Humanisme et Église en Italie et en France méridioale (XV siècle - milieum du XVI siècle), ed. Patrick Gilli (Rome: École français de Rome, 2004), 433-63, Timothy P. Dost, Renaissance Humanism in Support of the Gospel in Luther's Early Correspondence: Taking All Things Captive (Aldershot: Ashgate, 2001), and David C. Steinmetz, "Things Old and New: Tradition and Innovation in Constructing Reformation Theology" in Reformation \& Renaissance Review 19.1 (2017): 5-18.

6. Anthony Grafton documented five different genres of chronology, including the lists treated here; see Anthony Grafton, Historical Chronology (Oxford: Clarendon Press, 1993), 60-75; James W. Johnson, "Chronological Writing: Its Concepts and Development," History and Theory 2.2 (1962): 124-45.

7. The famous Italian humanist Annius of Viterbo (1432-1502) stated that chronology could benefit from the successions of public officers-such as kings and magistrates (reges et viri digerant)-because the generations marked their time (qui his temporibus floruerunt) through the preservation of their memory (et quorum memoriam teneant authores); see Annius of Viterbo, Antiquitates variae, Ioanne Pardo (1512) ch. 13, f. 91. Decades later, in 1556, the French philologist Robert Estienne published in Paris the ancient work of Dionysus of Halicarnassus, De praecipuis linguae Graecae auctoribus elogia, translated from Greek to Latin by the Polish scholar Stanisław Iłowski (d. 1589). In one of the appendices-a commentary on the theory of history (de historica facultate), in the section De distinctione historiae-Iłowski affirmed that historical facts can be considered and described in relation to human time, becoming a fundamental parameter to calculate chronology (actiones hominum tempore notentur atque describantur). In this way, the successions of institutional figures became a trustworthy tool for computation; Stanisław Iłowski, Dionysii Halicarnassei nonnulla opuscula, a Stanislao Ilovio Polono non primum Latinitate donata, quae quinta pagina recensentur. Eiusdem Ilovij et Robortelli de Historica facultate commentatiunculae (Paris: R. Estienne, 1556).

8. An interesting case is represented by the work of the German scholar Wolfgang Jobst (1521-75) who arranged a list of doctors from the beginning of medical science to his own time; see Wolfgang Jobst, Chronologia, siue Temporum supputatio, omnium illustrium Medicorum, tam ueterum quam recentiorum, 
established. ${ }^{9}$ Political successions were devoted to kings, emperors, dukes, and other authorities, while their ecclesiastical counterparts focused on popes and bishops.

Ecclesiastical chronotaxes have been arranged since the origins of Christianity and are based on "pontifical books" (Libri Pontificales) and "acts of pontiffs" (Gesta Pontificum). Initially, their structure was schematic in nature, with only names and corresponding dates provided; however, in the centuries that followed, the chronotaxes acquired more complexity as they started to include biographical information. However, the references for the data collected were often unreliable and frequently appeared contradictory, undermining the fidelity of the seriation. This situation gave great freedom to the compilers (most of whom were anonymous), allowing entire episcopal lineages to be fabricated in order to increase the prestige of the diocese concerned. ${ }^{10}$

A change occurred with the cultural revolution of humanism, which, through the diffusion of the antiquarian method, brought about a revised approach towards sources and the information they transmitted. Since the midfifteenth century, scholars have attempted to base their ecclesiastical seriations on tangible evidence in order to improve reliability.

This article represents the first time that the Renaissance ecclesiastical chronotaxes disseminated to Christian scholarly environments throughout Europe have been collated and studied. Several works (all printed editions), handing down at least one list of prelates, have been identified. On the basis of the data gathered thus far, it is reasonable to conclude that several other unknown or unpublished ecclesiastical chronotaxes have been written, perhaps including lower-level hierarchical posts. ${ }^{11}$ An overview of the practice is provided here.

in omni linguarum cognitione, a primis artis medicae inuentoribus \& scriptoribus (Franchfurt: Eichorn, 1556).

9. A significant example can be found in the relation established between the Roman Empire and the empire of Charles V, which retraced the path of all the predecessors who held the imperial crown and which involved also the entire debate on the Fasti Consulares.

10. Augusto Vasina, Vescovi e diocesi nella storiografia, in Vescovi e diocesi in Italia dal XIV alla metà del XVI secolo, ed. Giuseppina de Sandre Gasparini, Antonio Rigon, Francesco Trolese, and Gian Maria Varanini (Rome: Herder, 1990), 6-10.

11. See Paul Fridolin Kehr, Italia Pontificia sive repertorium privilegiorum et litterarum a Romanis Pontificibus ante annum MCLXXXXVIII Italiae ecclesiis, monasteriis, civitatibus singulisque personis 


\section{Chronotaxes and confessionalization}

In order to understand what reawakened the interest of Renaissance scholars in the genre of ecclesiastical chronotaxis, it is necessary to bear in mind the historical context and the cultural framework within which these works were disseminated. Generally, ecclesiastical chronotaxes were carried out in order to retrace the lineage of a specified religious institution, reconstruct its succession in order to reinforce its existence in the present, and confer further authority and legitimacy to the existing power structure. This was especially the case during the cultural expansion of the Reformation, when the authority of the ecclesiastical hierarchies became one of the most controversial issues discussed by theologians during confessional debates, especially the primacy of Peter, on which the election of the first bishops depended. ${ }^{12}$

This historical event was tied to the different interpretations of the Gospels (especially the Gospel of Matthew) and ancient patristic sources, not least the Constitutiones Apostolicae of Pope Clement I (d. $100 \mathrm{CE}$ ) and the Historia Ecclesiastica of Eusebius (265-340). According to the Catholics, it was Peter himself who elected the first bishops after his appointment as head of the Apostles, subordinating this office directly to papal control; according to the Protestants, however, there was no evidence that Peter had received

concessorum, 10 vols. (Berlin-Charlottenburg: Weidmannsche Verlagsbuchhandlung, 1961). This fundamental work reconstructs the history of the Italian dioceses by collecting primary sources; some chronotaxes are also mentioned.

12. On the Primacy of Peter see the fundamental monograph Paolo Prodi, Il sovrano pontefice: Un corpo e due anime: la monarchia papale nella prima età moderna (Bologna: Il Mulino, 1982); see also Domenico Grasso, Il primato di Pietro: fondamenti biblici e storici (Rome: Paoline, 1960); Antonio M. Javerre, La sucesion primacial y apostolica en el Evangelio de Mateo : resultado de una encuesta: datos para el problema de la sucesion apostolica (Torino: SEI, 1958). To understand the nature of this debate during the Renaissance see Ecclesiastica historia, integram Ecclesiae Christi ideam, quantum ad locum, propagationem, persecutionem, tranquillitatem, doctrinam, haereses, ceremonias, gubernationem, schismata, synodos, personas, miracula, martyria, religiones extra Ecclesiam, \& statum imperij politicum attinet, secundum singulas Centurias, perspicuo ordine complectens: singulari diligentia \& fide ex uetustissimis \& optimis historicis, patribus, \& alijs scriptoribus congesta: per aliquot studiosos \& pios uiros in urbe Magdeburgica (Basel: Oporino, 1559-74) and Onofrio Panvinio, De primatu Petri \& Apostolicae sedis potestate libri tres contra Centuriarum auctores (Verona: Discepolo, 1589); see also Damiano Acciarino, "Semantics and Ideology: 'Confessional Translations' of the Greek Word غ̇лíбколос," in Reformation \& Renaissance Review 19.1 (2017): 19-29. 
any primacy from Christ over the other Apostles, dissolving the first ring of the episcopal genealogy and abolishing the vertical structure of the Church's hierarchies in favour of the theory of the "universal priesthood." 13

If the sacredness of the episcopal institution was indeed considered to have descended from the primacy of Peter and to have been tied to the sacredness of the holy city of Rome, the apostolic origin of the dioceses would have legitimized the dominant role of the pope, i.e., with the pope prevailing over the Apostles. ${ }^{14}$ While the Protestants cast doubts over the authority of popes to elect bishops, and hence the nature of the episcopacy itself, the Catholics attempted to bring the foundation of the dioceses back to the Apostles, thereby conferring on this institution a sacred connotation that had spread since the birth of Christianity. It is therefore clear that ecclesiastical chronotaxes were directly influenced by these debates and susceptible to the occurrence of these dynamics.

\section{Lists of popes and bishops}

In this context, the Renaissance ecclesiastical chronotaxes appear to follow specific evolutionary patterns; however, although their contents essentially match the biographical sequence of lives, their starting points appear to change in accordance with the period of their composition, thereby causing the

13. This specific knot of the Renaissance culture between the Reformation and Counter-Reformation fits in a broader discussion on the relationship between spiritual and temporal power during the Tridentine age; see Paolo Prodi Il Concilio di Trento come crocevia della politica europea, ed. Hubert Jedin and Paolo Prodi (Bologna: Il Mulino, 1979), 65-75. For an overall vision on the episcopal issue during the Renaissance, see Viviane Barrie-Curien and Marc Vernard, La vita dei cristiani. Il Clero in Storia del Cristianesimo. Religione-Politica-Cultura. Il tempo delle confessioni (1520-1620/30), ed. Marc Venard (Rome: Edizioni Borla, 2001), 803-34, and Adriano Prosperi, La figura del vescovo tra Quattro e Cinquecento: persistenze, disagi e novità, in Storia d'Italia. Annali 9. La Chiesa e il potere politico dal Medioevo all'età contemporanea, ed. Giorgio Chittolini and Giovanni Miccoli (Turin: Einaudi, 1986), 219-63. Specific tractates on the ideal type of bishop were carried out in the late sixteenth century: see Hubert Jedin, Il tipo ideale di vescovo secondo la Riforma Cattolica (Cremona: Morcelliana, 1950), and Paul Broutin, Lévêque dans la tradition pastorale du XVI siècle (Bruges: Desclée, 1953). For the "universal priesthood” see Martin Luther, De captiuitate Babylonica Ecclesiae (Strasbourg: Johann Prüss 1520), De ordine: "Sic enim i. Pet. ii, dicitur, Vos estis genus electum, regale sacerdotium, et sacerdotale regnum. Quare, omnes sumus sacerdotes, quotquot Christiani sumus, Sacerdotes vero vocamus, ministri sunt ex nobis electi, qui nostro nomine omnia faciant. Et sacerdotium aliud nihil est, quam ministerium."

14. Heinrich Denzinger, Enchiridion Symbolorum, definitionum et declarationum de rebus fidei et morum (Barcelona, Freiburg, and Rome: Herder, 2009), 732. 
Protestant Reformation (1517) to emerge as the fundamental breaking point for this entire historiographic and editorial tradition. The chronotaxes below, which are arranged in a single corpus for the first time, present the development of this tendency and offer a standard definition of the genre.

1479: The first chronotaxis that can be defined as belonging to the Renaissance, mainly due to the humanistic education of its Italian author, Bartolomeo Platina (1421-81), is Vitae Pontificum. ${ }^{15}$ It is a chronological sequence of the lives of popes since the origins of Christianity (from Christ to Pope Sixtus IV), the purpose of which was to collect information on the history of the Church for the incumbent pontiff to follow as an example. In this work, Platina underlined the leading position taken by Peter over the other apostles in his description of the Pentecostal predications, where the Apostles travelled throughout the world to spread Christ's word. In terms of its structure and content, this work became an archetype of sorts, to be followed by future treatises on the same matter, and was emulated and contrasted by Catholic and Protestant scholars alike owing to the sensitive information it contained (including the flaws and crimes of popes).

1511: The episcopal chronotaxis entitled Catalogus episcoporum Olomucensium was published by the Moravian scholar Augustin Käsenbrot (1467-1513). ${ }^{16}$ The author outlined the names, the time in office, and a summary of the activities of each bishop of the Archdiocese of Olomouc, including all relevant actions carried out during their posts. As declared in the dedicatory text to Stanislav Thurzó, the bishop of the archdiocese at the time, Käsenbrot arranged this chronotaxis not only to preserve the religious history of Olomouc but also to be used as a model for future bishops. ${ }^{17}$ The two epitaphs on the frontispiece, written by the Swiss historian Joachim von

15. See Bartolomeo Platina, Historici liber de vita christi ac pontificum omnium qui hactenus ducenti et vigintiduo fuere, (Venice: Manthen, 1479 [first edition]), proemium; for the controversial biographical relationship of Platina with the Papacy, see Stefan Bauer, The Censorship and Fortuna of Platina's "Lives of the Popes" in the Sixteenth Century (Turnhout: Brepols, 2006).

16. August Käsenbrot, Catalogus episcoporum Olomucensium (Vienna: Singriener, 1511).

17. Käsenbrot, Catalogus, 3b: "dolebam enim eos per quos orthodoxae christianae religionis apud nos exordium coepit et tamquam per manus tradita ad haec usque tempora defluxit, aevi iniuria obsolescere nullisque annalibus seu litteraris monumentis commendatos caeca nocte ac oblivione involvi debere, quo nihil infoelicius in rebus humanis accidere reor." 
Watt (1484-1551), confirm this intent, underlining that the seriation of the names and accomplishments of past bishops would have reinforced the virtues of the bishop in office ("Nam dum clara legit praesul monumenta superstes / Nimirum virtus gratior inde sibi est"). Käsenbrot set the origins of the Diocese of Olomouc at the election of its first bishop, Cyrillus, by Pope Nicholas I in the ninth century, ${ }^{18}$ giving official pontifical sanction to the institution.

1546: The ecclesiastical seriation, Historia von der Bäpstund Keiser Leben, ${ }^{19}$ was arranged and published by Kaspar Hedio, the German historiographer and Protestant theologian. This work is a translation into German of Platina's Lives, to which Hedio added four chronotaxes, consisting of only names and dates: one for Roman pontiffs, one for emperors, one for popes who were the sons of priests or bishops, and one for councils and synods. Since Hedio's chronotaxes included a list of Catholic popes who were the sons of clergymen, thereby implying the intrinsic corruption of the Catholic Church and bringing its legitimacy into question, it appears that they were written with polemical intentions.

1549: In Northern Europe, another chronotaxis, De omnibus Germaniae episcopatibus, ${ }^{20}$ was published in 1549 by Kaspar Brusch (1518-59), a German humanist with an ambiguous confessional identity. ${ }^{21}$ This monumental work, the initial scope of which was to collect the episcopal successions throughout Germany, was left unfinished at the first volume, and limited only to the districts of Mainz and Bamberg. ${ }^{22}$ It is clear that there was a cultural and political

18. Käsenbrot, Catalogus, 3 a.

19. Kaspar Hedio, Platinae Historia von der Bäpst und Keiser leben: von Petro unnd Tiberio an biss auff Carolum V und Paulum III. Des Jars M. D. XLVI continuirt und zusammentragen (Strasbourg: 1546).

20. Gottfried Kreuz, Gaspar Brusch: Iter Anasianum: ein Spazierritt durch Oberösterreich 1552 (Vienna: Österreichische Akademie der Wissenschaften, 2008); Walther Ludwig, Gaspar Bruschius als Historiograph deutscher Kloster und seine Rezeption (Gottingen: Vandenhoeck \& Ruprecht, 2002).

21. Kaspar Brusch, Magni operis de omnibus Germaniae episcopatibus epitomes. Tomus primus continens Annales archiepiscopatus Moguntini ac duodecim aliorum Episcopatuum, qui Moguntino suffraganeatus titulo subsunt: item Babenbergensis episcopatus, ab omni iugo Archiepiscopali exempti (Nurberg: Neuber, 1549); the German scholar worked also on ecclesiastical archaeology, studying monasteries and cloisters of Germany and publishing a tractate of antiquarian erudition on this matter; see Kaspar Brusch, Monasteriorum Germaniae praecipuorum ac maxime illustrium: centuria prima. In qua origines, annales ac celebriora cuiusque monumenta, bona fide recensentur (Ingolstadt: Weissenhorn, 1551).

22. The archdiocese of Mainz was one of the Great Imperial Electors-as specified even in the title of the dedicatory to Bishop Sebastian von Heusenstein, Archiepiscopo Moguntino, Sacr. Rom. imperij per 
will to underline Mainz's deeply rooted Catholic tradition, since during the period 1514-17 this city triggered the Lutheran Ninety-Five Theses by granting indulgences and selling the vacant episcopate. ${ }^{23}$ This work may therefore have had an apologetic connotation that was tied to the original events of the Protestant Reformation. In fact, Brusch referred to the first bishop of Mainz, St. Crescentius, as one of the direct successors of the Apostles sent to Germany by St. Peter, recognizing the sacredness of the ecclesiastical hierarchy directly tied to the heirs of Christ ("Sanctus Crescens sive Crescentius, unus ex primis Germania Apostolis [...] Primus Moguntiam ad Christum convertit, et primus numeratur eius sedis antistes ac Episcopus"). ${ }^{24}$

1550: La chronique des roys de France, which is of French origin, is the work of the jurist and bishop Jean du Tillet (1521-70); ${ }^{25}$ both an imperial (Le catalogue des empereurs) and a pontifical (Le catalogue des papes) chronotaxis are included in the endnotes. It emerges from the letter to the reader, which was composed by the editor Jean d'Ongoys, that the text was written in Latin and originally only comprised a chronology of the kings of France. Only subsequently was it translated into French, with the other two series then added (the emperors and the popes).

1551: Reference to ecclesiastical chronotaxes is also made in the Commentarium Rei Publicae Romanae in exteris Provinciis by the Austrian Catholic doctor Wolfgang Laz, ${ }^{26}$ in which various short lists of bishops in office during the reign of Onorius (393-423 CE) and Arcadius (395-408 $\mathrm{CE}$ ) can be found. The chronotaxes taken into consideration concerned the Roman provinces of Africa, Illyria, the Middle East, Greece, Gaul, and Spain. The inclusion of ecclesiastical chronotaxes in a work that sought to describe the political structure of the Roman Empire outside of Italy is justified by the

Germanias Archicancellario et Electori.

23. Emidio Campi, "Nascita e sviluppi del protestantesimo," in Storia del Cristianesimo, ed. G. Filoramo and D. Menozzi, (Bari: Laterza, 2008), 14.

24. Brusch, Germaniae episcopatibus epitomes, 4.

25. Jean du Tillet, La chronique des roys de France puis Pharamond, iusques au roy Henry, troisiesme. Le catalogue des papes et le catalogue des empereurs (Paris: Ongoys, 1550). L'Imprimeur: "Soyez Lecteur adverty, que celuy qui a traduict ceste Chronique, ne scavoit point que l'Autheur mesme (qui vous est assez cognu encors qu'il n'ait iamais voulu y estre nomé et intitulé)."

26. Wolfgang Laz, Commentariorum reipub. Romanae illius, in exteris prouincijs, bello acquisitis, constitutae, libri duodecim (Basel: Johann Oporinus, 1551), bk. 2, ch. 2, 98-109. 
intention of the author to give institutional continuity to Christianity. In the section entitled de Sacris sedibus, which contains an analysis of the praetorium, Laz was able to discover the source from which the dioceses originated and developed ("istud praetorium ecclesiasticam administrationem acceperit" and "a praetorio ad Ecclesiam Christi translatis"). ${ }^{27}$

1557: Among the extensive works of the Italian friar, Onofrio Panvinio (1530-68), many concerned ecclesiastical chronology, ${ }^{28}$ including the Romanorum Pontifices et Cardinales. ${ }^{29}$ This was a chronotaxis that retraced the entire papal seriation from its origins up to the sixteenth century, including all the cardinals elected during each pontificate, and amended the errors made in previous series (mostly made by Platina) ${ }^{30}$ through the rigorous application of the antiquarian method.

1558: The English and Protestant theologian John Bale (1495-1563) published his catalogue of the lives of the popes, Acta Romanorum pontificum,

\section{Laz, Commentariorum reipub. Romanae illius, bk. 2, ch. 2, 98.}

28. Onofrio Panvinio, Epitome Pontificum Romanorum a S. Petro usque ad Paulum IV Gestorum (videlicet) electionisque singulorum, \& conclauium compendiaria narratio. Cardinalium item nomina, dignitatum tituli, insignia legationes, patria \& obitus. Onuphrio Panuinio Veronensi f. augustiniano authore. Ex Musaeo Iacobi Stradae Mantuani, ciuis Romani, antiquarij (Venice: Jacopo Strada, 1557); Romanorum Pontifices et Cardinales S.R.E. ab eisdem a Leone IX ad Paulum papam IV per quingentos posteriores a Christi Natali annos creati (Venice: Michele Tramezzino, 1557); B. Platinae Historia de vitis Pontificum Romanorum, à D. N. Iesu Christo usque ad Paulum papam II. Longè quàm antea emendatior; cui Onuphrij Panuinij Veronensis fratris eremitce Augustiniani opera, reliquorum quoque pontificum uitee usque ad Pium IV pontificem maximum adiunctee sunt. Et totum opus varijs annotationibus illustratum (Venice: Michele Tramezzino, 1562); Chronicon Ecclesiasticum. A C. Iulii Caesaris dictatoris imperio, vsque ad imp. Caesarem Maximilianum II Austrium (Cologne: Cholinus, 1568); XXVII pontificorum maximorum elogia, \& imagines accuratissime ad viuum aeneis typeis delineatae (Rome: Accolti, 1568).

29. This work had two simultaneous editions, both printed in Venice in 1557: the first was carried out by the printer Jacopo Strada, not licensed by the author and full of errors; see the epistolary exchange between Panvinio and Ottavio Pantagato in Antonia Soler i Nicolau, La correspondècia d'Ottavio Pantagato (1494-1567), doctoral thesis directed by Dr. Joan Carbonell i Manils (Universitat Autònoma de Barcelona, Bellaterra, 2000). The second was carried out by Michele Tramezzino, with the supervision of the author himself, who tried to amend the preceding spurious version; see Panvinio, Romanorum Pontifices et Cardinales, ad lect.

30. An important case could be indicated in the identification of Pope John VIII, discrediting the legend of the Pope Joan; see Panvinio, Romanorum Pontifices et Cardinales, 50; Panvinio, Platinae Historia de vitis Pontificum Romanorum 101-102 and passim; Stefano Zen, Baronio storico: Controriforma e crisi del metodo umanistico (Naples: Vivarium, 1994), ad ind.; Soler i Nicolau, 128-30. 
referring openly to Platina's work. ${ }^{31}$ Bale's chronotaxis included items that had already been added by Kaspar Hedio, including the list of popes fathered by married churchmen, once again for the purpose of discrediting Catholic institutions.

1558: Another interesting example of a chronotaxis is the Elenchus theologorum in tota sacra Biblia, ${ }^{32}$ which was written by the German Catholic theologian Georg Witzel (1501-73). In this work, he put in chronological order all the prophets and theologians present in the Holy Writ, including the Old and New Testaments and all the authors of the Patrology, whether Jewish, Greek, or Latin. At the end of the book, another chronotaxis was included entitled Series temporum quibus claruerunt Scriptores Ecclesiastici, which comprised an alphabetical list of the interpreters of ecclesiastical texts with the dates of their works.

1562: The first chronotaxis of the French clergy ${ }^{33}$ can be identified in the extensive treatise Christianae religionis institutionisque historica propugnatio, written by Antoine de Mouchy (1494-1574), a Catholic theologian and inquisitor who took part in the Council of Trent in 1563. His work, divided into four tomes, ${ }^{34}$ the second of which is entirely devoted to reconstructing

31. John Bale, Acta Romanorum pontificum, a dispersione disciplinorum Christi, usque ad tempora Pauli quarti, qui nunc in Ecclesia tyrannizat (Basel: Oporinus, 1558).

32. Georg Witzel, Elenchus theologorum in tota sacra Biblia (Cologne: Maternum Cholinum, 1558). This theologian also worked on other lists related to the Holy Writ and to Patristic texts; see Georg Witzel, Catalogus sanctorum veteris testamenti, sacris e bibliis erudite con textus (Cologne: Quentel, 1549).

33. See also the earlier works on the institutional division of the French territory where the dioceses of France are indicated: Jaques Signot, La totale et vraie description de tous les passaiges, lieux \& destroictz: par lesquelz ou peut passer \& etrer des Gaules es ytalies. Et signamment par ou passerent Hannibal, Jiulius cesar, \& ... les roys de France Charlemaigne, Charles 8., Louis 12. Et le tresillustre roy Francois ... Item plus est contenu le nombre et titres des cardinaulx et patriarches. Lordre et le noms des archeueschez, \& eueschez estans en luniuersel monde. Item les archeueschez: eueschez: abbayes: \& aultres benefices reseruez au sainct siege apostolique. Auec la taxe ordinaire: estans au royaume et segneuries de la courronne de france (Paris: Touissant, 1515) and Numerus et tituli cardinalium, archiepiscoporum \& episcoporum christianorum. Tazae et valor beneficiorum regni Galliae: quibus addita sunt multa quorum indicem sequenti pagella reperies (Paris: Du Pré and Augereau, 1533).

34. Antoine de Mouchy, Christianae religionis, institutionisque Domini Nostri Iesu Christi et apostolicae traditionis, aduersus Misoliturgorum blasphemias, ac nouorum huius temporis sectariorum imposturas, praecipuè Ioannis Caluini \& suorum contra sacram Missam, catholica \& historica propugnatio (Paris: Macé, 1562). 
the ecclesiastical seriations of France, Germany, and Austria, was intended to oppose and discredit the Protestant doctrinal positions formulated by Jean Calvin. Of all the catalogues it contains, those of the archbishops and bishops of France are the most complete and detailed: the episcopal lists for the most important dioceses are traced back to the first preachings of the successors of the Apostles, the majority of whom were appointed by St. Peter. Among these, the worthiest of consideration is that of Reims: its episcopal lineage began in $316 \mathrm{CE}$, but De Mouchy set the effective origin of this office to the first century CE, which is when St. Sixtus, St. Sinisius, and St. Amasius were sent to Gaul by St. Peter to preach.

1569: The French scholar Pierre Pithou (1539-96), a Catholic who abjured Protestantism in 1588, included the chronotaxes arranged by St. Nikephoros of Constantinople (eighth century) at the beginning of his edition of the Historia miscella. ${ }^{35}$ These seriations featured in several ecclesiastical lists, in which the Patriarchs of Jerusalem were listed after Jesus Christ, and the names of the bishops of the city were listed under those of the Christian Roman emperors and the bishops of Rome, Byzantium, Alexandria, and Antioch. Pithou also arranged another chronotaxis for the diocese of Troyes in France, which was entitled Bref recueil des evesques de Troyes and published in 1600 in the appendix of his Les costumes du baillage de Troyes en Champaigne. This list begins with St. Amator, a bishop and martyr (fourth century CE), but he alludes to previous preachings in that territory by St. Savinianus, who was appointed directly by St Peter. ${ }^{36}$

1572: A second chronotaxis of English origin, De antiquitate Britannicae Ecclesiae, ${ }^{37}$ which was published by Matthew Parker (1504-75), the Anglican Archbishop of Canterbury, included a list of the archbishops of Canterbury, from the origins of the diocese to that time, supporting the legitimacy of the local episcopal position. Parker dated the foundation of the Church of England

35. Pierre Pithou, Historiae miscellae a Paulo Aquilegiensi Diacono primum collectae, post etiam à Landulpho Sagaci auctae (Basel: Perna, 1569).

36. Pierre Pithou, Les costumes du baillage de Troyes en Champaigne. Avec quelques annotations sur icelles (Paris: Abel l'Angelier, 1600), 503-25; on the first bishop of Troyes, see Hugo Mathoud, De vera Senonum origine christiana, adversus Iohannis de Launoy theologi quondam Parisiensis criticas observationes (Paris: Lagronne, 1687), 32-33.

37. Matthew Parker, De antiquitate Britannicae ecclesiae, et nominatim de priuilegis ecclesiae Cantuariensis, atque de archiepiscopis eiusdem 70. Historia, (Hanau: Wechel and Marne, 1572). 
back to the first apostolic preaching in ancient times, contesting the view held by the Church of Rome ("non a Romana sede, ut Pontificii contendunt"). ${ }^{38}$ He stated that, on the basis of patristic sources, the first Christian to preach in Britain was St. Paul; however, he also proposed alternative figures, such as Joseph of Arimathea or St. Simon Apostle. ${ }^{39}$

1576: The objectives of the ecclesiastical chronotaxis SS. Episcoporum Veronensium monumenta, which was written by the Italian priest Raffaello Bagatta (sixteenth century), were to collect information about the lives of the bishops of Verona and to safeguard examples of the Christian virtue that they represented ("exempla passionis"). However, since the seriation was not chronological but alphabetical in order, and included only the bishops of the city for whom there was evidence of proven sanctity, it appears to be an exception among the ecclesiastical seriations of the Renaissance. ${ }^{40}$ It is likely that this choice was linked to the idea that a chronological arrangement was not necessary because a confirmation of virtue went beyond time and other contingencies.

1582: Another chronotaxis from Italy is the Catalogus episcoporum Brixinensium, which was written by the Italian canon Donato Fezzi (156497). Like the works of his predecessors, Fezzi reconstructed the chronotaxis of the Diocese of Brescia in order to encourage the incumbent bishop to follow the examples of those who had previously held his position. ${ }^{41}$

1584: Hollandiae historia comitum, written by the Flemish scholar Adrian Barland (ca. 1486-ca. 1540), carried an appendix Item Vltraiectensium episcoporum catalogus et res gestae, in which there was a chronotaxis detailing the lives and actions of the bishops of Utrecht. ${ }^{42}$ Historia veterum episcoporum

\section{Parker, 1.}

39. Parker, 4-5; see also Grafton, “Church History in Early Modern Europe," 16.

40. Raffaello Bagatta, S.S. Episcoporum Veron. antiqua monumenta et aliorum sanctorum quorum corpora, et aliquot, quorum ecclesiae habentur Veronae (Venice: Bocchino, 1576), ad lect.

41. Donato Fezzi, Catalogus episcoporum Brixinensium, usque ad haec nostra tempora omnium, prout ex vetustissimis scriptis colligere licuit: quae etsi rudi admodum stilo constent, nihil tamen immutandum duximus quia simplex huiusmodi ordo, nonnunquam fidelius incorruptae antiquitatis veritatem exprimere videatur (Brescia: Fezzi, 1582).

42. Adrian Barland, Hollandiae comitum historia et icones: cum selectis scholiis ad lectoris lucem. Eiusdem Barlandi Caroli Burgundice ducis vita. Item Vltraiectensium episcoporum catalogus et res gestoe. Eiusdem argumenti Libellus Gerardo Nouiomago auctore (Lion: Plantin, 1584). 
Ultraiectensium, by Sjoerd Pieters (1527-97), published posthumously in 1612, and which partially reformulated the seriation proposed by Barland, was also related to this diocese. ${ }^{43}$

1585: The Italian monk and scholar Vincenzo Borghini (1515-80) worked on an ecclesiastical chronology when drafting Discorsi, his antiquarian treatise on the city of Florence. He attached a dissertation on the Florentine church and its bishops, Trattato della Chiesa e Vescovi fiorentini, ${ }^{44}$ in which a seriation of the lives of the Florentine bishops was arranged. ${ }^{45}$ The aim of this work was to reconstruct a new and faithful chronotaxis of the Florentine episcopate, from its origins to modern times, since a series of mistakes had been gradually accumulated throughout the years and retransmitted, confusing the lineage. ${ }^{46}$ Despite declaring that he did not have primary sources to guarantee the veracity of his claim, Borghini attributed the origins of the Florentine episcopate to the most direct successors of the Apostles-in this case, Saint Frontin and Saint Paulin, who had been nominated directly by Peter. ${ }^{47}$ In this way, Borghini sought to draw a direct connection between the origin of the Florentine diocese and the first pontiff, establishing an original link with the city of Rome.

1586: The Italian scholar Carlo Sigonio (1520-84) wrote De episcopis Bononiensibus, a chronotaxis of the bishops of Bologna. His seriation began with St. Zama, a bishop sent by Pope Dionysus in the second century CE. The objective of his chronotaxis was compatible with those composed by other Catholic authors: in fact, he affirmed that the first purpose of episcopal

43. Sjoerd Pieters, Historia veterum episcoporum Vltraiectinae sedis, \& comitum Hollandiae, explicata Chronico Iohannis de Beca canonici Vltrajectini ab anno nativitatis Christi usque ad annum 1345. Et Historia Guilhelmi Hedae praepositi Arnhemensis auctoris nunquam editi, completa appendice usque ad annum Christi 1574 (Franeker: Doyema, 1612).

44. Vincenzio Borghini, Discorsi di monsignore don Vincenzio Borghini. Al serenissimo Francesco Medici gran duca di Toscana, 2 vols. (Florence: Giunti, 1584-85), 2:351-595. Another chronotaxis on the dioceses of Tuscany concerned the bishops of Arezzo: see Jacopo Burali, Vite de vescoui aretini (Arezzo: Gori, 1638).

45. To retrace Borghini's antiquarian pathway see Gino Belloni and Riccardo Drusi, Filologia e invenzione nella Firenze di Cosimo (Florence: Olschki, 2002).

46. In working on his chronotaxis, Borghini exchanged views with Onofrio Panvinio, as proved by many letters; see Carlo Roberto Dati, Raccolta di prose fiorentine. Volume terzo, parte quarta, contenente lettere (Florence: Tartini and Franchi, 1743), part 4, bk. 4, 52-61, 186-87.

47. Borghini, 2:357-58: "Però piglisi per ora il principio da costui, pur con questa condizione; e quando se ne troverrà alcuna più salda certezza, si potrà come cosa chiara affermare." 
sequences was to fight the heretical positions of the Protestants ("et quia continentem Catholicorum antistum seriem ad confutandos haereses in primis pertineret putarunt"). ${ }^{48}$

1594: The Italian clergyman Gaspare Mosca (sixteenth century) published a treatise entitled De Salernitanae ecclesiae episcopis, et archiepiscopis catalogus, in which he included a list of all the bishops of Salerno. ${ }^{49}$ Mosca turned the uncertainty over the origins of the Church of Salerno in favour of a direct apostolic derivation. He attempted to include the episcopate of Salerno among those founded by the disciples of St. Peter, despite no evidence of this having been found in the original source. ${ }^{50}$ However, Mosca convincingly stated that, if these consecrations had in fact taken place ("Quod si verum est, ut certe arbitramus veri simillimum"), the number of bishops elected would have been higher ("multo plures fuisse in illa Episcopos necesse est, ac multorum nomina, et res gestae ad nos non pervenisse"), hinting that the importance of Salerno in the ancient world meant it had to be among those missing.

1596: The Dutch scholar Pieter van Opmeer published Catalogus omnium totius prope orbis archiepiscoporum episcoporumque. The initial aim of this work was to compile all of the archiepiscopal seriations of the Christian world in Germany, Italy, France, England, Scotland, Scandinavia, Hungary, Bohemia,

48. Carlo Sigonio, De episcopis Bononiensibus (Bologna: Benatio, 1586), 1-2.

49. Gaspare Mosca, De Salernitanae ecclesiae episcopis, et archiepiscopis catalogus (Naples: Stigliola, 1594).

50. Clement I, Diatagai ton agion apostolon dia Klementos tou Romaion episkopou te kai politou katholike didaskalia dia biblion okto (Venice: Ziletti, 1563). The understanding of these texts occurred previously: in a letter of 27 November 1557, Spanish bishop Antonio Agustin, in an attempt to help the scholar Onofrio Panvinio to prepare his pontifical cronotaxes-Panvinio, Epitome Pontificum Romanorum and Romani Pontifices et Cardinales - set down a list of sources that could have been useful in extracting information in the study of ecclesiastical chronology, among which was the Constitutiones Apostolicae of Pope Clement I. See Joan Carbonell, Epigrafia i numismatica a l'epistolario d'Antonio Agustin (1551-1563), doctoral thesis directed by Dr. Marc Mayer i Olive (Universitat Autònoma de Barcelona, 1991) 195-200: “Quanto alli Patriarchi mostrerò a M. Agnolo vostra lettera, ed esso vi risponderà: Io desidero che vedesti bene delli decretali, nel decreto, nel sesto, nelle clementine, et extravaganti, et nelli concilii la memoria di tutti questi cardinali, et vescovi, che cercate. Son certo che troverete più d'uno et vi confermarete in molti." Agustìn, on 6 April 1559, underlined once again this passage: "Dalle costituzioni apostoliche di Clemente si desumono le ordinazioni vescovili fatte dagli apostoli” (Carbonell, 373-75); Giovanni Carlo Bovio, De constitutionibus apostolicis, B. Clemente Romano auctore, libri VIII (Lyon: Rouillé, 1564), bk 7, pp. 46, 110 a-b; see also Act. Ap., 1:8. 
Poland, Spain, Belgium, and the Middle East, but this was ultimately narrowed down to focus solely on Germany. ${ }^{51}$

1597: Antonio Maria Spelta, an Italian Catholic scholar, published a seriation of the bishops of the Diocese of Pavia, in northern Italy, entitled Historia delle vite di tutti $i$ vescovi di Pavia. Spelta proved that the episcopate of the city was founded by St. Syrus, who had been consecrated directly by St. Peter with a mission to evangelize the territory. ${ }^{52}$

1605: The Spanish theologian Francisco Padilla (1527-1607) published his monumental treatise Historia Ecclesiastica de España, drafting several seriations of popes, emperors, the Gothic and Swabian kings of Spain, Councils held in Spain, Spanish bishops without a specific office, and ancient bishops who had no succession. After these catalogues, he commenced work on a chronotaxis for all of the Hispanic dioceses, ordered alphabetically. ${ }^{53}$ Padilla took it for granted that the Church of Spain had been founded directly by St. James, the brother of St. Peter. In fact, all the episcopal lists included in Padilla's collection had their apostolic legitimacy assured by this provenance. ${ }^{54}$

1606: Another important chronotaxis from Spain, Historia de las antiguedades de la cividad de Salamanca,${ }^{55}$ was written by the scholar González de Ávila (1578-1658). This work is divided into three sections: the first describes the foundation of the city until the first evangelical preaching; the second lists the names and short lives of the first bishops until the foundation of the University of Salamanca (1218); and the third registers all the subsequent

51. Pietr van Opmeer, Catalogus omnium totius prope orbis archiepiscoporum episcoporumque ab illo tempore, quo christiana religio originem sumpsit, ad haec nostra vsque secula: qui contra misoliturgos missae sacrificium asseruerunt. Multa hic \& scitu atque obseruatione necessaria ac lectu iucunda traduntur atque explicantur (Cologne: Lützenchirchen, 1596).

52. Antonio Maria Spelta, Historia di Antonio Maria Spelta cittadino pauese, delle vite di tutti $i$ vescoui, che dall'anno di nostra salute 45. fino al 1597 (Pavia: Bartoli, 1597).

53. Franciso Padilla, Historia ecclesiastica de España que contiene cinco centurias en que se trata del principio y progressos que tuuo la religion christiana en España, y de los santos martires, confessores, obispos, y concilios (Malaga: Bolan 1605).

54. This was one of the most important points of Hispanic historiography during the Renaissance, as pointed out by Katherine E. Van Liere, "Renaissance Chroniclers and the Apostolic Origins of Spanish Christianity," in Sacred History: Uses of Christian Past in the Renaissance World (Oxford: Oxford University Press, 2012), 121-44; see Padilla, vol. 2, index.

55. Gil González de Ávila, Historia de las antigüedades de la ciudad de Salamanca (Salamanca: Taberniel, 1606). 
bishops. Just like Padilla, González de Ávila also started his episcopal succession from St. James and his nine disciples, reinforcing the direct ancient connotation between the Church of Spain and an apostolic mandate.

1612: Novaria seu de Ecclesia Novariensi was a treaty of ecclesiastical erudition carried out by the Italian scholar Carlo Bascapè (1550-1615). The work is divided into two sections: the first describes the territory of the Diocese of Novara and the second its bishops throughout history. Bascapè had no data at his disposal to prove that the diocese had existed since the origins of Christianity. In fact, the first bishop of the city was considered to be St. Gaudentius (fourth century $\mathrm{CE}$ ); however, he took the view that the first evangelization of the city, and therefore the first diocese, should have been traced back to the apostolic preachings in Milan, ${ }^{56}$ not far from Novara. ${ }^{57}$

1621: The French jurist Jean Chenu (1559-1627) arranged all the chronotaxes of France into two volumes entitled Archiepiscoporum et episcoporum Galliae chronologica historia..$^{58}$ This work was openly inspired by his compatriot De Mouchy, reaffirming the polemical nature of this genre for the purpose of contrasting the confessional positions of Protestants ("ad impugnandum illius temporis haereticos") with the nature of ecclesiastical hierarchies by reconstructing the apostolic descent of the entire episcopal lineage. ${ }^{59}$

1626: Only five years later, the French presbyter and historian Claude Robert (1564-1637) published another vast chronotaxis of all the dioceses and monasteries of France entitled Gallia Christiana. ${ }^{60}$ With references included for the name of each bishop and the period of incumbency, this work was more schematic in nature than those of his predecessors. Robert sought to prove

56. On the history of the diocese of Milan see Giuseppe Ripamonti, Historia Ecclesiae Mediolanensis (Milan: Collegium Ambrosianum, 1617-25).

57. Carlo Bascapè, Nouaria seu De ecclesia Nouariensi libri duo primus de locis, alter de episcopis (Novara: Sesalli, 1612), 233-34: "Ita Mediolano Evangelicae veritatis nuncios cito Novariam advenisse credibile est, in urbem, neque longe positam [...] atque moribus non dissimilem."

58. Jean Chenu, Archiepiscoporum et episcoporum Galliae chronologica historia. Qua ordo eorumdem a temporibus apostolorum incoeptus, ad nostra vsque, per traducem succedentium seruatus, ostenditur (Paris: Buon, 1621).

59. Chenu, Archiepiscoporum et episcoporum Galliae chronologica historia, I, II.

60. Claude Robert, Gallia christiana, in qua regni Francice ditionumque vicinarum dioeceses, et in iis proesules describuntur (Paris: Cramoisy, 1626). 
that the office of the episcopacy dated back to the origins of Christianity, and this was actually demonstrated by retracing the episcopal lineage to apostolic descent. Furthermore, an objective of his chronotaxis was to hand down positive examples given by previous bishops in order to help the entire Catholic Church on its path of salvation by encouraging their emulation ("ad excitandam virtutum aemulationis"). ${ }^{61}$

1644-62: The ideal closing point of this overview is represented by Italia Sacra sive de episcopis Italiae, ${ }^{62}$ the nine-volume work by the Cistercian monk Ferdinando Ughelli (1595-1670). ${ }^{63}$ Ughelli arranged a series of chronotaxes that included all the bishops of Italy, ordered by geographical area (the twenty regions of Italy), publishing the largest and most documented work on the ecclesiastical historiography of his times. His aim was to present Italy as the cradle of Christianity through the exhibition of all its dioceses and the longlasting episcopal lineage connected to the establishment of the Holy See in Rome. ${ }^{64}$

\section{The method}

In order to draw a clearer distinction between the cultural and editorial phenomena of the ecclesiastical chronotaxes written during the Renaissance, and to understand the authors' intentions, it is useful to observe the method applied. In fact, the methodological choices reflect the context in which they were prepared and the reasons for which they were used.

61. Robert, Gallia christiana, ad lect.

62. First edition: Ferdinando Ughelli, Italia sacra siue De episcopis Italioe et insularum adiacentium, rebusque ab iis praeclare gestis, deducta serie ad nostram vsque atatem. Opus singulare prouincijs 20. distinctum. In quo ecclesiarum origines, urbium conditiones, principum donationes, recondita monumenta in lucem proferuntur, 9 vols. (Rome: Tani, 1644-62). Second edition: Ferdinando Ughelli, Italia sacra sive De episcopis Italioe, et insularum adjacentium, rebusque ab iis proclare gestis, deducta serie ad nostram usque atatem. Opus singulare provinciis 20. distinctum, in quo ecclesiarum origines, urbium conditiones, principum donationes, recondita monumenta in lucem proferuntur (Venice: Coleti, 1717-22).

63. On this important scholar see the bibliography found in Adelisa Malena, "Ferdinando Ughelli," in Il contributo italiano alla storia del pensiero, Ottava Appendice, vol. Storia e politica (Rome: Istituto dell'Enciclopedia Italiana, 2013), 272-78.

64. (1: Santa Sede; 2: Emilia, Flaminia, Piceno, Umbria; 3: Etruria; 4: Insubria, Liguria, Piemonte; 5: Veneto e Istria; 6: Campania, Abruzzo, Irpinia; 7: Lucania, Basilicata, Puglia; 8: Benevento and suffraganee; 9: Salento, Calabria). 
What emerges is that the method applied by each author was described in detail only from the mid-sixteenth century onward. In his introductory poem, Kaspar Brusch (1549) was the first to outline the sources of his episcopal chronotaxis: ancient inscriptions ("veterum saxa et monumenta legenda"), which implied that the author had epigraphic knowledge; ancient books ("ex antiquis excipienda libris"), which demonstrated that the texts were understood in their original language; manuscripts ("inquirendae Bybliothecae"), which attested to the philological and linguistic cognitions; the archaeological findings of monasteries ("Monastica templa"), which were difficult to interpret ("non satis apta legi"), implying palaeographic abilities; and sculptures of all kinds ("omnigenas statuas"), which also required an understanding of art history. ${ }^{65}$ These are all typical elements of antiquarian investigation and were developed through the experience of humanists throughout Europe, who drew on their knowledge of ancient history and classical sources in an attempt to link historical events to the tangible reality of the findings handed down.

The antiquarian method was used by many authors. In the work of Jean du Tillet (1550), for example, the seriations were taken from a consistent number of textual extracts, papers, monuments, and various authentic antiquities ("d'un bon nombre d'extraictz, chartres, monumens, et ancinnetez authentiques"). ${ }^{66}$ Onofrio Panvinio (1557) attested to having found inspiration in the study of profane history ("res veteres profanas") when commencing his works on sacred history ("sacras historias"), which also appears to imply an assimilation of antiquarian techniques. Panvinio stated that he had utilized sepulchral eulogies ("sepulchrorum elogijs"), ancient inscriptions ("vetustatisque inscriptionibus") taken from the Roman basilicas ("per varias urbis basilicas"), as well as chronicles ("ex chronacis") and fragments of historiographic texts ("concisis historijs"). ${ }^{67}$ Raffaello Bagatta (1576) also utilized ancient codices of various

65. Brusch, Germaniae episcopatibus epitomes, Introduction: "Plurima erunt veturum saxa et monumenta legenda, / Plura ex antiquis excipienda libris. / Nec tibi erunt paucae inquirendae Bybliothecae / Illic cum tineis bellum erit acre tibi. / Sic adeunda tibi sunt saepe Monastica templa/ Multa legenda ubi erunt non satis apta legi ./ [...] / Omnia templa pio affectu studioque pererrans, / omnigenas statuas, omnia saxa legens."

66. Du Tillet, La chronique des roys de France, "Letter to the Reader."

67. Panvinio, Romanorum Pontifices et Cardinales, ad lect. In addition to these sources, those used for the heraldic reconstruction were included in the seriation that was referenced by Jacopo Strada in the preface of his non-authorized edition, which included paintings in churches and palaces (in Templis aut 
origin ("ex diversis locis, antiquis codicibus") as well as local ecclesiastical writings ("scripturis nostrarum Ecclesiarum") and epigraphs ("lapidibus"). Similarly, in the brief preface to his work, Fezzi (1582) examined ancient texts ("vetustissimis scriptis colligere") which were difficult to read ("rudi admodum stilo") and had to be preserved in their original form ("nihil immutandum") since they resulted in more faithful and reliable interpretations ("fidelius incorruptae antiquitatis veritatem exprimere").

The particular attention devoted to ancient texts was also in line with Vincenzo Borghini's method. He indicated that the "origin of errors" derived from "retouching" sources. Usually, this practice was applied in order to render the texts more comprehensible to readers of different periods. However, the content was modified irreparably as a result: with the manipulation/ simplification of texts, the original forms were contaminated and, consequently, the original thoughts were lost. ${ }^{68}$ The instruments utilized to interpret these sources were various and depended on the quality of the finding under examination. It was only thanks to the crossing over of data of the original documents and other specific evidence-such as epigraphic, numismatic, and archaeological findings - that his chronotaxis acquired a certified reliability. In addition to reporting on the state of affairs, including documental vacuities, Borghini was also well aware that the lack of documentation, especially for the first few centuries, meant it would be impossible to make a list without omissions. ${ }^{69}$

Ughelli also devoted the same level of attention to the original language of ancient sources. In the preface to his work, he affirmed that the quotations from ancient tables, diaries, calendars, epigraphs, inscriptions, sepulchral eulogies,

Palatijs picta), sepulchral statues (in sepulchris sculpta), decorative apparatus of altars (in toto altarium apparatu), drapes and carpets (aulaeis ac tapetibus), and ornaments of various kinds (in argenteis ac aureis instrumentis); see Panvinio, Epitome Pontificum Romanorum, ad lect. To arrange his chronotaxis, Panvinio received the help of various scholars, such as the Italian humanist Ottavio Pantagato and the Spanish bishop Antonio Agustìn. Agustìn, in particular, indicated many sources from which it was possible to obtain useful data to arrange the ecclesiastical catalogues; see Joan Andrès, A. Augustini Archiepiscopi Tarraconensis, Epistolae latinae et italicae (Parma: Mussi, 1804), 19:293-94; 20:294-97; 23:299-302; 25:305-06; 42:359-60; and Carbonell, 195-200.

68. Borghini, 2:340; see also Vincenzio Borghini, Lettera intorno a' manoscritti antichi, ed. Gino Belloni (Rome: Salerno, 1995).

69. Borghini, 2:342. 
official documents, reports, etc., should always have been considered in their original form, drawing even greater attention to the importance of using the same words ("ipsissima verba"). This was for the same reasons as those explained extensively by Borghini, i.e., that the modification of any text leads automatically to its irreparable corruption. ${ }^{70}$

\section{Conclusions}

From these analyses on the genre of ecclesiastical chronotaxis carried out during the Renaissance, it is possible to draw some general conclusions which may provide another perspective on the subject.

The first is that the number of publications of printed chronotaxes appears to have increased after the mid-sixteenth century, in conjunction with the consolidation of the Protestant Reformation. It is clear that the number of editions published after the 1540s is much higher than in the decades before. Of course, the catalogue presented above represents only a limited sample of the entire production of chronotaxes throughout Europe in the early modern period; however, it can be used to present a rough indication of some of the wider dynamics connected to the genre.

This leads to the second conclusion. Ecclesiastical chronotaxes appear to have a didactic function with a moral connotation. In most cases, the authors openly declare their intent to encourage the incumbent bishop or pope to follow the virtuous example of his predecessors. This inclination should be included among the reforming tendencies of the entire clergy that pervaded the Church after the beginning of the fifteenth century. ${ }^{71}$ Thus, in an attempt to respond to the new spiritual demands emerging from the disputes with Protestants, the genre of chronotaxis also appears to have had an anti-corruption function regarding the clergy within the hierarchies.

The third conclusion is that ecclesiastical chronotaxes had the function of legitimizing the institution to which they referred: reconstructing the episcopal lineage from its origins meant reinforcing the ideal structure of the diocese by demonstrating its real continuity in time. Here came the "right to exist" of each episcopate, since its foundation was rooted in a divine manifestation. 
Given the data collected, it is possible to hypothesize that the breakout of the Protestant Reformation encouraged scholars to direct their efforts even more rapidly towards linking the dioceses with an apostolic foundation, for the purpose of reinforcing the link with the origins of the Church. This was in fact the most crucial aspect of the entire issue: the apostolic genesis conferred upon the episcopal office a "divine right" ("de iure divino"), with its authority derived directly from Christ without any mediation, thereby further supporting its legitimacy.

Nevertheless, this right could have been quite ambiguous, especially if interpreted by those who sought to reduce or even abolish the "pontifical right" on the episcopacy ("de iure pontificio"), to which all the dioceses were subjected owing to the dogma of the primacy of Peter. It was not only that Protestant scholars, who repudiated the ecclesiastical hierarchies, attempted to undermine the power of the Roman pontiff; they were also joined by Catholics who sought greater independence for their national church. ${ }^{72}$

The argument could be made that this conflict is reflected in the works of the Spanish scholars Francisco Padilla and Gil González de Ávila, who traced back the foundation of the Church of Spain to St. James, and of the English scholar Matthew Parker, who believed either St. Paul or St. Simon to be the founder of the Church of England.

These secessionist ideas began to be voiced by the Spanish prelates at the Council of Trent during the discussions of the "episcopal issue" in 1563, with greater sovereignty demanded from the Church of Rome, and a demand to exclude pontifical interference from the divine right of the episcopacy.

On the other hand, the episcopal chronotaxis, even if spreading from a reformed environment, was arranged for the purpose of confirming the ecclesiastical hierarchies inherited by the Anglican Church. In this way, Parker sought to support the original independence of the Church of England, openly legitimizing the schism that had occurred thirty years before. Therefore, even on this occasion, the apostolic descent ended up reinforcing the existence of the institution but severing bonds with the Roman Catholics.

However, what emerges from the Italian, French, and German publications appears to be quite different. In the Italian context, it is clear that the scholars

72. Giuseppe Alberigo, Lo sviluppo della dottrina sui poteri nella chiesa universale: momenti essenziali tra il 16. e il 19. secolo (Rome: Herder, 1964), 11-99. 
attempted to connect the dioceses directly to St. Peter and hence to a pontifical foundation, as demonstrated by the cases of Vincenzio Borghini, Gaspare Mosca, and Carlo Bascapè. The reason for this tendency remains uncertain, but the local episcopates may have attempted to increase their influence on the territory by strengthening their ties with the Roman Curia. This could also be supported by the work of Ughelli, which portrayed Italy as the most virtuous herald of the Christian religion in Europe-perhaps in an attempt to reinforce its role in competition with the other national churches.

A similar attitude can be observed in France and Germany. In the cases of Caspar Brusch, Antoine De Mouchy, Jean Chevu, and Claude Robert, the intention was to trace back the birth of their dioceses to the disciples of St. Peter, probably for the purpose of reinforcing the bond with the Roman Catholic Church in the period of spiritual and political crisis that led to the religious wars. ${ }^{73}$ In fact, the declaration of direct descent from Rome, for instance, by the dioceses of Mainz and Reims (which elected the emperor and consecrated the kings of France, respectively) was intended to reaffirm the Church's power over these secular and political institutions.

Furthermore, given the political situation in France between the late sixteenth and early seventeenth centuries, the question arises as to the nature of the relationship between the chronotaxes promoted by these scholars (all Catholics) and the work carried out in 1594 by Pierre Pithou on the freedom of the French National Church, Les libertez de l'eglise Gallicane. ${ }^{74}$ This intersection of contrasting cultural perspectives is likely to shed greater light on the complex weave of connections that various scholarly environments may have had with the political and ecclesiastical establishment.

The ecclesiastical chronotaxes were used mainly in a Catholic environment for the purpose of enhancing the institution under examination, either by consolidating or dissolving the bond with Rome. When used by the Protestants, however, chronotaxes always had a polemical implication and were always related to the work of Bartolomeo Platina, who was generally considered close to Protestant authors. As can be seen in the opening poem of Bale's treatise

73. Nancy Lyman Roelker, One King, One Faith: The Parlement of Paris and the Religious Reformations in the Sixteenth Century (Berkeley: University of California Press, 1996), 226-72.

74. However, these actions must be considered in relation to the research conducted on the independence of the Church of France, which is well expressed by the treatise of Pierre Pithou on the original freedom of the Church of Gaul; see Pierre Pithou, Les libertez de l'eglise Gallicane (Paris: Patisson, 1594). 
Onus seu prophetia Romae, written by the English Puritan Lawrence Humphrey (1526-89), Platina ranked just behind Luther among the most important authors to criticize the Roman Papacy ("Plurima Lutherus patefecit, Platina multa / Quaedam Vergerius, cuncta Baleus habet"). In fact, the objective of the two chronotaxes created by the Protestant scholars Kaspar Hedio and John Bale was to demonstrate that the Catholic ecclesiastical hierarchy had incorporated evil manifestations over the centuries.

In response to these aggressions aimed at overthrowing the secular structure of the Catholic Church, Catholic scholars began to put the explanation of the method applied before their chronotaxes. By describing the sources taken into consideration and the antiquarian approach towards them, the data collected were deemed to be more reliable and trustworthy, providing actual, tangible evidence in support of the examples of virtue bequeathed by each episcopal lineage. In this way, material evidence of sanctity, the purpose of which was to confirm the full legitimacy and the full right of the episcopal institution to exist, became an instrument in confessional disputes. The words of Gaspare Mosca on the true nature of chronotaxes and how were they perceived by the Catholic world offer a clear reading of this tendency: ${ }^{75}$

Sicut contra, Dei Civitatem perpetua, sanctissimaque Episcoporum successione constitutam, nos Catholici ubique ostendimus, et exhibemus.

(On the other hand, we the Catholics recognize and display the constitution of the City of God in the eternal and holy succession of bishops). 